\title{
Over-expression of adenosine deaminase in mouse podocytes does not reverse puromycin aminonucleoside resistance
}

\author{
Gaëlle Brideau, Alain Doucet ${ }^{*}$
}

\begin{abstract}
Background: Edema in nephrotic syndrome results from renal retention of sodium and alteration of the permeability properties of capillaries. Nephrotic syndrome induced by puromycin aminonucleoside (PAN) in rats reproduces the biological and clinical signs of the human disease, and has been widely used to identify the cellular mechanisms of sodium retention. Unfortunately, mice do not develop nephrotic syndrome in response to PAN, and we still lack a good mouse model of the disease in which the genetic tools necessary for further characterizing the pathophysiological pathway could be used. Mouse resistance to PAN has been attributed to a defect in glomerular adenosine deaminase (ADA), which metabolizes PAN. We therefore attempted to develop a mouse line sensitive to PAN through induction of normal adenosine metabolism in their podocytes.
\end{abstract}

Methods: A mouse line expressing functional ADA under the control of the podocyte-specific podocin promoter was generated by transgenesis. The effect of PAN on urinary excretion of sodium and proteins was compared in rats and in mice over-expressing ADA and in littermates.

Results: We confirmed that expression of ADA mRNAs was much lower in wild type mouse than in rat glomerulus. Transgenic mice expressed ADA specifically in the glomerulus, and their ADA activity was of the same order of magnitude as in rats. Nonetheless, ADA transgenic mice remained insensitive to PAN treatment in terms of both proteinuria and sodium retention.

Conclusions: Along with previous results, this study shows that adenosine deaminase is necessary but not sufficient to confer PAN sensitivity to podocytes. ADA transgenic mice could be used as a background strain for further transgenesis.

\section{Background}

Nephrotic syndrome is defined by abnormal urinary excretion of proteins leading to hypoalbuminemia. These biological signs are secondary to alterations of the glomerular filtration barrier. The primary forms of the disease correspond to either genetic alterations of proteins involved in the glomerular filtration barrier or to the idiopathic nephrotic syndrome which is due to a circulating factor that functionally alters the glomerular barrier. Whatever its etiology, nephrotic syndrome is always associated with renal retention of sodium which,

\footnotetext{
* Correspondence: alain.doucet@crc.jussieu.fr

Laboratoire de génomique, physiologie et physiopathologie rénales, Université Pierre et Marie Curie, Institut National de la Santé et de la Recherche Médicale, Centre National de Recherche Scientifique, 15 rue de l'Ecole de Médecine, Paris, 75270 cedex 6, France
}

along with alterations of the permeability properties of the capillary wall, promotes ascites and/or edema [1]. The most widely used animal model to study sodium retention in nephrotic syndrome is a rat model that reproduces the biological and clinical signs of the human disease $[2,3]$. It is induced by a single injection of puromycin aminonucleoside (PAN), an adenosine derivative used as an antibiotics and anti-proliferative drug that also induces nephrotic syndrome in humans.

Previous studies in nephrotic rats have shown that sodium retention results from stimulation of its reabsorption in the aldosterone sensitive distal nephron [4-6] and from resistance of the terminal collecting duct to the effect of atrial natriuretic peptide $[7,8]$. Increased sodium reabsorption originates in principal cells where both apical sodium entry via the epithelial sodium 
channel $\mathrm{ENaC}$ and basolateral exit via $\mathrm{Na}, \mathrm{K}$-ATPase are increased [6,9]. Although $\mathrm{ENaC}$ and $\mathrm{Na}, \mathrm{K}$-ATPase are known targets of aldosterone [10,11], and although plasma aldosterone is increased in PAN nephrotic rats [3], sodium retention is independent of aldosterone $[6,12]$. As a matter of fact, sodium retention is not accounted for by variations in any endocrine system since it affects only the treated kidney in unilateral PAN-induced nephrotic syndrome [5]. Several alternate hypotheses have been proposed to explain sodium retention, but they have not been unambiguously validated, as this would require genetic invalidation of hypothesized target genes. Unfortunately mice do not develop nephrotic syndrome in response to PAN, and no mouse model of nephrotic syndrome featuring the signs of the human disease exists yet.

Interspecies differences in sensitivity to PAN have been associated with differences in the adenosine metabolism pathway. Thus, Nosaka et al. [13] showed that sensitivity to PAN of different species was correlated with their renal adenosine deaminase (ADA) activity: Among the species they studied, rats and mice displayed the highest and lowest ADA activity respectively, and were the two prototypes of PAN sensitivity and resistance in term of proteinuria. The same group also showed that pre-treatment of rats with the ADA inhibitor 2'-deoxycoformycin prevented PAN-induced proteinuria and glomerular lesions [13]. More recently, Xia et al. [14] showed that adenosine and PAN enter cells via the plasma membrane amine transporter (PMAT) which is expressed specifically in podocytes in both rat and human. Overexpression of PMAT in MDCK cells increased their sensitivity to PAN, an effect which was abolished by decynium 22, a potent inhibitor of PMAT [14]. Thus, low expression of PMAT in mouse podocyte might also account for PAN resistance.

In an attempt to develop a mouse line sensitive to PAN through induction of normal adenosine metabolism in podocytes, we sought to determine whether or not PMAT expression in mouse glomerulus might be limiting in order to engineer mice expressing ADA and, if necessary PMAT, in their podocytes through transgenesis using a podocyte specific promoter. The sensitivity to PAN was evaluated on the basis of its ability to induce urinary excretion of proteins and to reduce sodium excretion in transgenic mice as compared to littermates. Rats were studied in parallel as positive controls.

\section{Methods}

\section{Transgenesis plasmid construction}

Plasmid containing the human NPHS2 promoter was kindly provided by $\mathrm{C}$ Antignac (Hôpital Necker, Paris). Oligonucleotide primers were designed to PCR amplify a $2.6 \mathrm{~kb}$ fragment of NPHS2 promoter located upstream the NPHS2 initiation codon (sense: 5'-GAAGATCTCAGCTGGCCCTCCTATTTAGTCTCTCTGCCACC-3' and antisense: 5'-CCCGGCAGCTCTGACCATGGTACCCC-3'). The sense and antisense primers contained $B g l \mathrm{II}-P v u \mathrm{I}$ and $K p n \mathrm{I}$ sites respectively. This promoter fragment was cloned at the BglII and KpnI sites of pCi vector (Promega) in place of CMVI.E promoter and intron sequences. Similary, oligonucleotide primers were designed to PCR amplify from mouse kidney cDNAs the full length mouse ADA cDNA (sense: 5'-AAGGAAAAAAGCGGCCGCGGAACCATGGCCCAGACACCCGCATTCAACAA-3', and antisense: 5'TTCTCCTTTTGCGGCCGCCTAAGCATAATCCGGTACATCATACGGGTATTGGTATTCTCTGTAGAGCCGT-3'). These two primers contained a NotI site, and the antisense primer also encoded a hemagglutinin tag before the stop codon. The ADA cDNA was cloned at NotI site of pCi vector, dowstream the NPHS2 promoter fragment. Finally, the modified $\mathrm{pCi}$ vector was digested with $N c o$ I to remove the vector fragment remaining between the promoter and the ADA cDNA. The sequences of all constructs were checked by sequencing. After amplification and $P v u \mathrm{I}$ digestion, the transgenesis plasmid (Figure 1) was purified. Generation of transgenetic mice in $\mathrm{FVB} / \mathrm{n}$ genetic background was performed by the Service d'Expérimentation Animale de Transgénèse (CNRS UPS 44, Villejuif, France). Generation of this mouse transgenic line and its study were performed with the approval of the French Ministère de l'Enseignement Supérieur et de la Recherche (approval \# 5197, april 16, 2009).

\section{Transgene detection by PCR}

Transgenic mice were identified by PCR on DNA recovered from tail biopsies. Tail fragments of 1 month-old

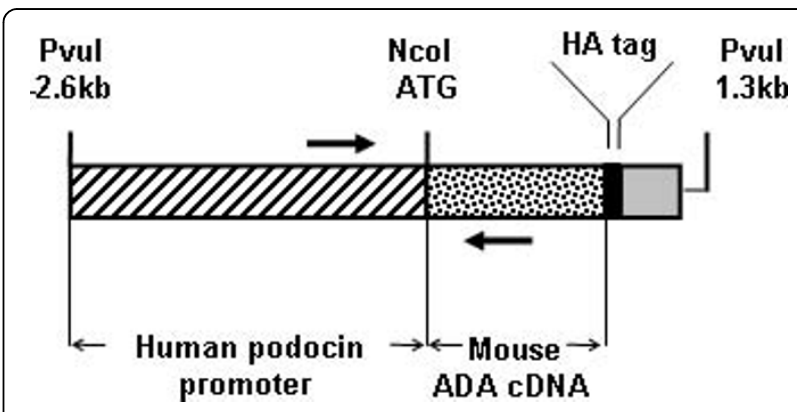

Figure 1 Schematic structure of the NPHS2-promoter/ADA transgene. The transgene construct carried a 2.6-kb DNA fragment located upstream the translated region of the human NPHS2 (hatched) gene followed by the mouse ADA cDNA (dotted). A HAtag was introduced at the $3^{\prime}$ end of ADA (black), just before the stop codon. Finally, the poly-adenylation (grey) sequence corresponds to the SV40 Late poly(A) from pCi vector. Arrows indicate the location of primers used for PCR genotyping of mice. 
mice were lyzed overnight at $55^{\circ} \mathrm{C}$ in TNES solution (100 mM Tris- $\mathrm{HCl} \mathrm{pH} \mathrm{8.5,} 200 \mathrm{mM} \mathrm{NaCl}, 10 \mathrm{mM}$ EDTA, $0.2 \%$ SDS) containing $0.66 \mathrm{mg} / \mathrm{ml}$ proteinase $\mathrm{K}$ (Invitrogen). Proteinase $\mathrm{K}$ was inactivated $5 \mathrm{~min}$ at $95^{\circ} \mathrm{C}$. The transgene was identified by PCR $\left(\mathrm{GoTaq}^{\circ} \mathrm{DNA}\right.$ polymerase, Promega, 35 cycles, Tm: $65^{\circ} \mathrm{C}$ ) using primers located in the promoter and in ADA regions respectively (Figure 1): sense, 5'-TGCAGACACGCACTTTTCAA-3'; reverse, 5'-GCCATCAAGAGGATCGCCTA-3'

\section{Microdissection}

Glomerulus, cortical collecting ducts (CCD) and proximal convoluted tubules (PCT) were dissected from liberase-treated kidneys (Blendzyme 2, Roche Diagnostics) as previously described [15]. Briefly, the left kidney was perfused in situ with $6 \mathrm{ml}$ of Hank's solution supplemented with $1 \mathrm{mM}$ glutamine, $1 \mathrm{mM}$ pyruvate, $0.5 \mathrm{mM}$ $\mathrm{MgCl}_{2}, 0.1 \%$ bovine serum albumin, $20 \mathrm{mM}$ Hepes, and $0.015 \%$ liberase $(\mathrm{w} / \mathrm{v}), \mathrm{pH}$ 7.4. Thin pyramids were cut from the kidney and incubated in $0.006 \%$ liberase solution for $20-25 \mathrm{~min}$ at $30^{\circ} \mathrm{C}$ and thoroughly rinsed in microdissection solution supplemented with a cocktail of protease inhibitors (Complete EDTA-free, Roche Diagnostics) when used for western blot. For RNA extraction, tissues were isolated under Rnase-free conditions.

\section{Western blot analysis}

After microdissection, pools of 50 to 60 glomerulus, PCT or CCD were solubilized at $95^{\circ} \mathrm{C}$ for $5 \mathrm{~min}$ after addition of $2 \times$ Laemmli. SDS-PAGE was performed on $10 \%$ polyacrylamide gels and proteins were transferred to Hybond ${ }^{\mathrm{Tm}}$-P membrane (GE Healthcare) using standard procedure. Blots were blocked in 5\% non-fat dry milk in TBS-Nonidet P-40 buffer (50 mM Tris base, $150 \mathrm{mM} \mathrm{NaCl}, 0.2 \%$ Nonidet P-40) and incubated with a specific rat anti-HA antibody (Roche diagnostics; dilution 1/1 500), and incubated with a secondary horseradish peroxidase-linked anti-rat antibody (Jackson Immunoresearch, Ltd). Immunodetection was performed using enhanced chemiluminescence light detecting kit (Amersham, Arlinghton Heights, IL, USA).

\section{RNA extraction and RT-QPCR}

RNAs were extracted from pools of 50-60 glomerulus using RNeasy Plus Micro Kit (Qiagen) according to the manufacturer's instructions. Reverse transcription was performed on $80 \%$ of glomerular RNA extract using the first-strand cDNA synthesis kit for reverse transcriptionPCR (Roche Diagnostics), according to the manufacturer's instructions. The remaining $20 \%$ of glomerulus RNA extract were processed in parallel in the absence of reverse transcriptase and served as controls. No amplification product was detected in these controls in any experiment.

Real-time PCR was performed on a LightCycler (Roche Diagnostics) with the LightCycler 480 SYBR Green I Master qPCR kit (Roche Diagnostics) according to the manufacturer's instructions, except that the reaction volume was reduced to $10 \mu \mathrm{l}$. PCR was performed in the presence of cDNA corresponding to 1 glomerulus. Specific primers (available upon request) were designed using Light Cycler probe design software II (Roche Diagnostics).

\section{Animals}

All animal experiments were carried out according the French legislation, under the responsibility of an enabled experimenter (AD, license \#75-699 renewal). Nephrosis was induced in male Sprague Dawley rats (160-200 g, Charles River, France) by a single administration of PAN (150 mg/kg body wt, jugular vein). In mice, PAN was administered either once or twice $(150-300 \mathrm{mg} / \mathrm{kg}$ body wt, retro-orbital or jugular vein injection).

Animals were acclimatized to metabolic cages for at least two days before PAN administration. 24-h urine was collected for determination of sodium, creatinine, and proteins on an automatic analyzer (Konelab 20i, Thermo, Cergy Pontoise, France). Urinary sodium and protein excretions were calculated as a function of urinary creatinine excretion. Animals were sacrificed at the end of the experimental period (6-10 days after PAN injection).

\section{Determination of ADA specific activity}

The method used was previously described by Chinsky et al. [16]. Rat and mouse kidneys were placed in ice cold $0.1 \mathrm{M}$ potassium phosphate, $\mathrm{pH} 7.4$ buffer containing $1 \mathrm{mM}$ 2-mercaptoethanol and were lysed by Polytron. Cell debris were removed by microfuge centrifugation $\left(10 \mathrm{~min}\right.$ at $\left.4^{\circ} \mathrm{C}\right)$. Protein content of homogenates was estimated by the method of Bradford. ADA activity was assayed at room temperature in a reaction mixture containing $0.14 \mathrm{mM}$ adenosine, $50 \mathrm{mM}$ potassium phosphate, $\mathrm{pH} 7.4$ and tissue homogenate. The decrease in absorbance at $260 \mathrm{~nm}$ resulting from deamination of adenosine to inosine was monitored every $10 \mathrm{~s}$ with a spectrophotometer and the rate of inosine production was determined under initial rate conditions [17].

\section{Results}

\section{Expression of ADA and PMAT in mouse and rat} glomerulus

The expression levels of ADA and PMAT determined by RT-QPCR in mouse and rat glomerulus were 
compared. For this purpose, we calculated the amount of each transcript as:

$$
\mathrm{Q}=\mathrm{K} / \mathrm{L} \times \mathrm{Eff}^{\mathrm{CP}}
$$

in which $\mathrm{K}$ is a transcript-independent constant, $\mathrm{L}$ is the amplicon length, Eff is the PCR efficiency and $C_{p}$ is the threshold of fluorescence detection, determined as the number of PCR cycles at which the reaction fluorescence reaches its second derivative maximum [18].

Expression of ADA was very low in the glomerulus of mouse as compared to that of rat. In contrast, mRNA expression level of PMAT was $~ 4$-fold higher in mouse glomerulus than in rat glomerulus, but the difference was not statistically significant (Figure 2). Thus, as opposed to ADA, PMAT did not appear to be a limiting factor for PAN metabolism by mouse podocytes. We therefore decided to promote normal adenosine metabolism in mouse glomerulus by generating a mouse line over-expressing ADA in podocytes.

\section{Transgenic mice}

For this purpose, a 2.6-kb fragment of DNA located upstream from the human NPHS2 transcribed region was selected to drive the expression of ADA in podocytes. This fragment was selected because its gene product, podocin, is specifically expressed in podocytes [19] and because it was previously used successfully to drive expression of another transgene in these cells [20]. Trangenic mice were generated by pronuclear injection in $\mathrm{FVB} / \mathrm{n}$ mice. Five transgenic founders were identified by PCR analysis of genomic DNA, among which one died a few weeks after birth, one was unable to reproduce, and

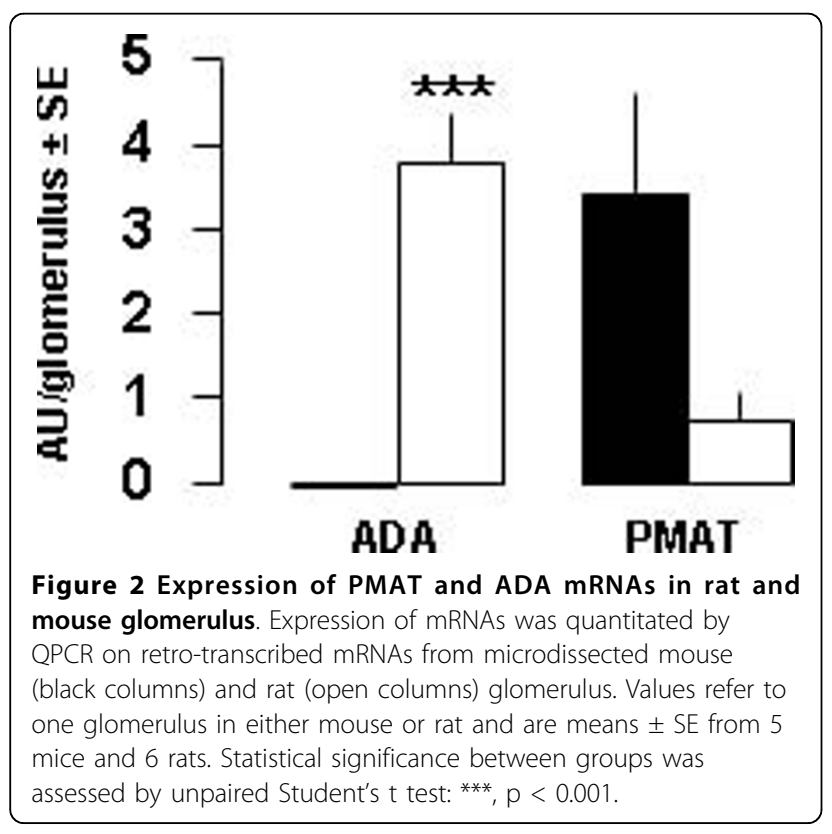

one failed to transmit the transgene to its progeny. The last two founders transmitted the transgene to their progeny (mouse lines 2 and 3 ) but only line 2 expressed ADA at the protein level (Figure 3A). As expected from the promoter used to drive ADA expression, kidney expression was restricted to the glomerulus.

Because introduction of the HA-tag could have altered protein function, we evaluated ADA activity in the kidney of transgenic mice from line $2\left(\mathrm{ADA}^{\mathrm{tg}}\right)$. ADA activity was $\sim 18$-fold higher in $\mathrm{ADA}^{\text {tg }}$ mice than in wild types (Figure 3B). It was also $\sim 4$-fold higher than in rat kidney.

\section{Effect of PAN}

As previously reported [3,9], a single injection of PAN (150 mg/kg body wt) to rats induced a marked

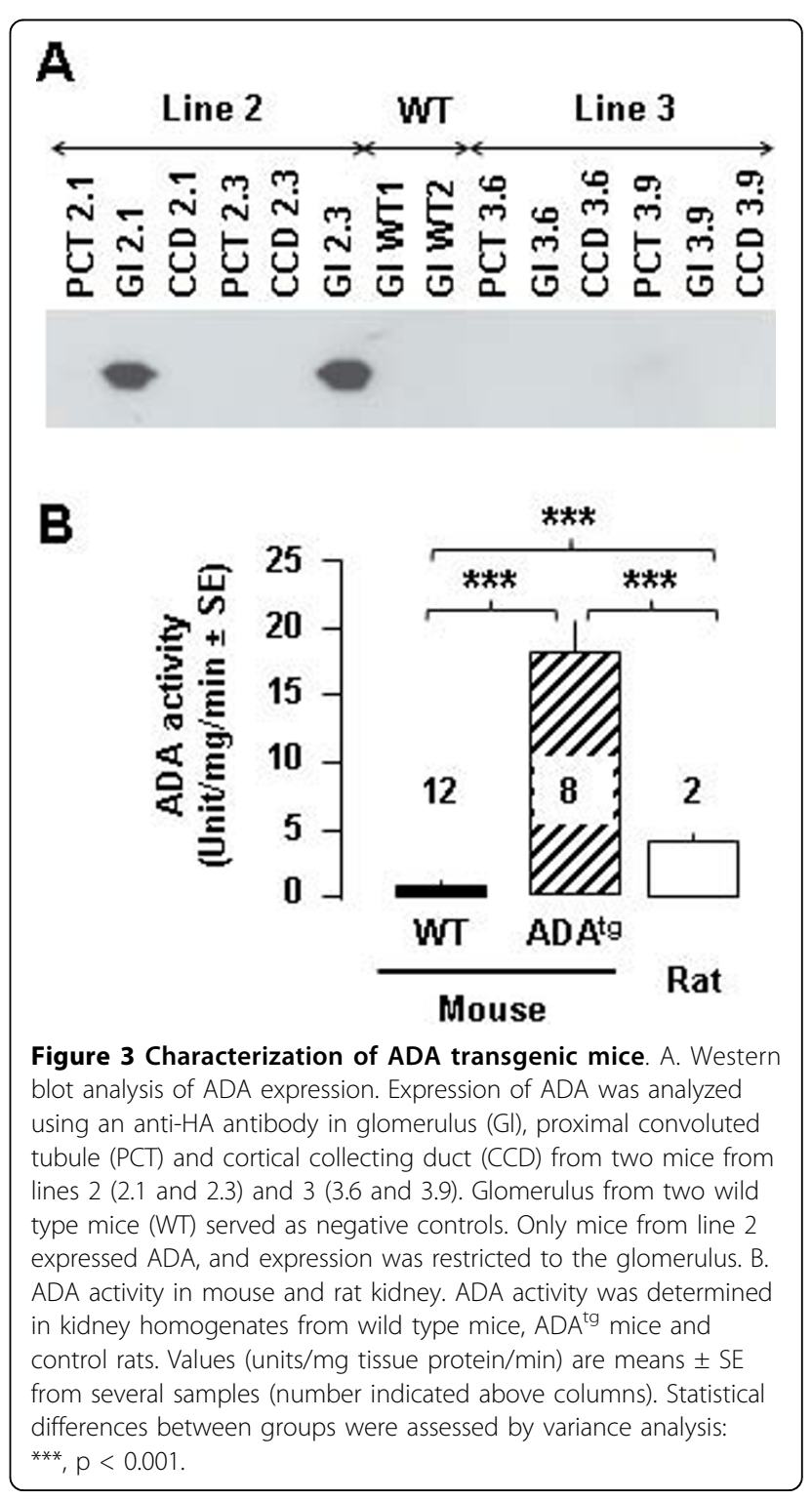


nephrotic syndrome with severe proteinuria $(\sim 10 \mathrm{~g} / \mathrm{mmol}$ creatinine) and decreased sodium excretion $(<5 \mathrm{mmol} /$ mmol creatinine) (Figure 4A). Note that administration of PAN induced a transient (day 1) increase in sodium excretion which has been attributed to cytotoxicity. In contrast, a single administration of PAN (150 mg/kg body wt) to wild type mice did not alter significantly their urinary excretion of proteins and sodium, except for the transient increase in sodium excretion at day one (Figure 4B, dotted lines). Note also that conversely to rats, mice displayed a basal proteinuria, in the range of $0.5-2 \mathrm{~g} / \mathrm{mmol}$ creatinine.
In $\mathrm{ADA}^{\text {tg }}$ mice, $\mathrm{PAN}$ neither increased proteinuria nor induced marked sodium retention. However, it slightly and transiently reduced sodium excretion, as compared with wild type mice, at days 3 and 4 (Figure 4B, solid lines). Extending the monitoring up to 14 days failed to reveal proteinuria or sodium retention in either wild type or $\mathrm{ADA}^{\text {tg }}$ mice (data not shown). Higher doses of PAN (up to $300 \mathrm{mg} / \mathrm{kg}$ body wt) also failed to induce a nephrotic syndrome in either group of mice (data not shown)

In a final experimental series, we investigated whether a second administration of PAN might amplify its
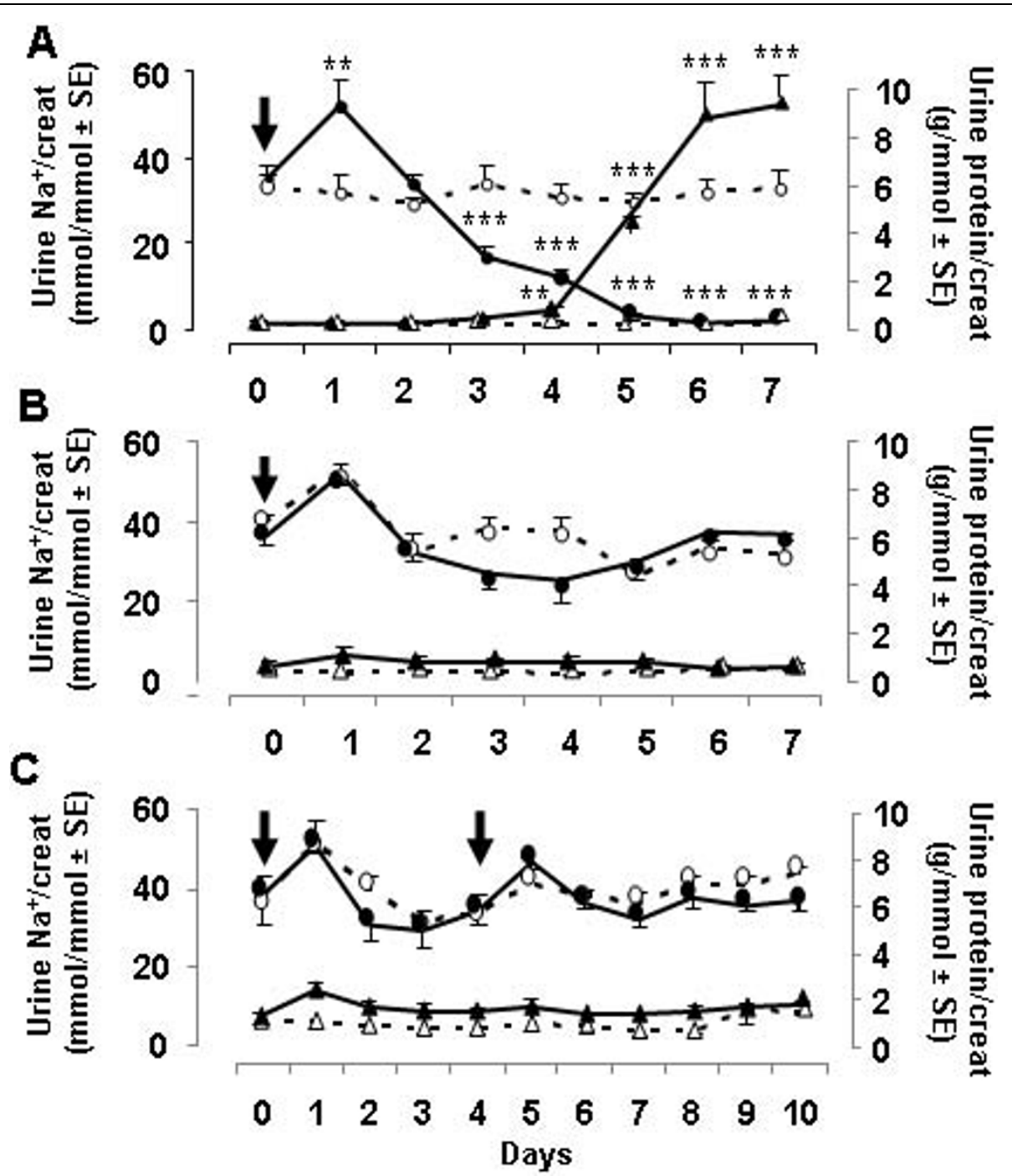

Figure 4 Effect of PAN treatment on urinary excretion of proteins and sodium. A. Effect of PAN in rats. PAN-treated (150 mg/kg body wt at day 0 , solid lines) and -untreated rats (dotted lines) were housed in metabolic cages and their daily excretion of sodium (circles) and proteins (triangles) was monitored for 7 days. Results, expressed as a function of creatinine excretion, are means \pm SE from 6 rats in each group. Statistical significance between treated and untreated rats was assessed by unpaired Student's $t$ test: ${ }^{* *}, p<0,025 ;{ }^{* *}, p<0,001$. B and $C$. Effect of PAN in wild type and $A D A^{\text {tg }}$ mice. Wild type (dotted lines) and $A D A^{\text {tg }}$ mice (solid lines) received a single (B) or two (C) injections of PAN (150 mg/kg body wt at day 0 and day 4, arrows) and were monitored for 7-10 days for urinary excretion of sodium (circles) and proteins (triangles). Results, expressed as a function of creatinine excretion, are means \pm SE from 6 mice in each group except the ADA ${ }^{\text {tg }}$ group treated once $(n=9)$. Values statistically different from controls (day 0) were assessed by variance analysis followed by Bonferonni test: *, $\mathrm{p}<0.05$. 
transient effect on sodium excretion and induce proteinuria in $\mathrm{ADA}^{\text {tg }}$ mice. Figure $4 \mathrm{C}$ shows that two successive administrations of PAN (150 mg/kg body wt) at days 0 and 4 failed to induce proteinuria or sodium retention. In contrast, the two injections promoted a transient increase in sodium excretion, attesting the efficiency of PAN.

\section{Discussion}

PAN-induced nephrotic syndrome in rat has been widely used for determining the structural alterations of the filtration barrier responsible for proteinuria and the functional changes responsible for tubular sodium retention. However, the mechanism of action of PAN is not fully understood. PAN is thought to promote proteinuria through a cytotoxic effect on podocytes. Early experiments in which a unilateral nephrotic syndrome was induced by transient infusion of PAN in one kidney while preventing its access to the general circulation have demonstrated that proteinuria results from a rapid and direct effect of PAN on the kidney. Several observations suggest that PAN needs to be metabolized to be nephrotoxic. Firstly, inhibition of ADA prevents PAN-induced proteinuria in rats [13]. As a matter of fact, PAN is a structural analogue of adenosine, the natural substrate of ADA (figure 5). However, PAN differs from adenosine by an amino group substitution of the hydroxyl group on carbon 3 of the ribose ring, and by a dimethylamino substitution of the purine amino group. Thus, it is unclear whether ADA catalyzes the deamination of the ribose or the removal of the dimethylamino residue of the purine, or both. Secondly, PAN-induced nephrotic syndrome is associated with the early production of reactive oxygen species (ROS) in the glomerulus [21-23] and treatment with ROS scavengers or antioxidants reduces or prevents proteinuria $[22,24,25]$. Interestingly, hypoxanthine is a metabolite of PAN [26] generated by the removal of the dimethylamino residue of the purine that acts as a substrate for ROS generation by xanthine oxidase [24].

Because the resistance of mouse podocytes to PAN was attributed to their deficiency in adenosine<smiles>OCC1OC(n2cnc3[14cH]ncnc32)C(O)C1O</smiles>

Adenosine

Inosine<smiles></smiles>

\section{Puromycin}

\section{aminonucleoside}

\section{Hypoxanthine}

Figure 5 Structure of adenosine, PAN and metabolites. Blue and red lettering indicate the structural differences between adenosine and PAN, and the changes induced by ADA action respectively. ADA, adenosine deaminase; $X O$, xanthine oxidase; ROS, reactive oxygen species. 
deamination pathway [13], we attempted to render mouse podocytes sensitive to PAN by promoting the expression of the adenosine deamination pathway that has been observed in rat podocytes. In order to be metabolized by ADA, PAN first has to enter podocytes via PMAT [14]. In this study we showed that PMAT is expressed in mouse glomerulus at least at the same level as in rat glomerulus, and through transgenesis we promoted a podocyte ADA activity slightly higher than in rat. Transgenesis was performed on FVB mice because this background has proven to be more susceptible to the development of proteinuria and ascites $[27,28]$. Nonetheless, whatever the dose and/or the number of PAN injections, these ADA transgenic mice developed neither proteinuria nor sodium retention. These results suggest that PAN metabolism by ADA is not sufficient to induce PAN sensitivity in mouse.

Over the past decade, many laboratories tried to develop a mouse model mimicking human nephrotic syndrome (Table 1). Three different strategies were developed. The first one consisted in selecting or generating a genetic background to render mice sensitive to PAN, as attempted in this study. The second one was to induce proteinuria by altering the genetic expression of proteins central to the filtration barrier. The last one aimed at generating idiopathic nephrotic syndrome through induction of the production of a permeability factor by immune cells.

Results from the present study as well as several previous ones $[13,29]$ have documented the resistance of mouse to the nephrosis-inducing effect of PAN. Increased sensitivity to PAN, in term of proteinuria, has been reported in mice over expressing cycloxygenase- 2 in a podocyte-specific manner (nephrin promoter) [29] as well as in apolipoprotein $\mathrm{E}$ deficient, hypercholesterolemic mice [30]. However, in both cases, proteinuria was moderate (3- to 5-fold increase) and was rapidly reversible as it was no longer detected after 8 days. In contrast, Kanwar et al. reported over 30 years ago that repeated administration of PAN induced a massive, nephroticrange proteinuria in hyperprolinemic mice ( $\mathrm{PRO} / \mathrm{Re})$ with a natural deficiency in proline oxidase [31]. The possible link between PAN metabolism and proline oxidase remains obscure and, curiously, these results have never been confirmed since their publication, despite the major interest in disposing of a mouse model of nephrotic syndrome. No information is available regarding sodium metabolism and/or edema or blood pressure in any of these models.

To alter the glomerular filtration barrier, investigators have targeted genes encoding proteins essential for the structure and function of either the glomerular basement membrane (laminin $\alpha 5$ and $\beta 2$ ) or the podocytes and slit diaphragm (Nphs2, CD2-AP, CD151 and
Table 1 Animal models of proteinuria

\begin{tabular}{|c|c|c|c|}
\hline Models & Proteinuria & Na handling & Ref \\
\hline \multicolumn{4}{|l|}{ Injection of PAN } \\
\hline \multirow[t]{4}{*}{ Sprague Dawley rat } & $10 \mathrm{~g} / \mathrm{mmol}$ creat & $\begin{array}{l}\text { Ascites, } \\
\text { edema }\end{array}$ & {$[9]$} \\
\hline & $90 \mathrm{mg} / \mathrm{mg}$ creat & $\begin{array}{l}\text { Ascites, } \\
\text { edema }\end{array}$ & {$[9]$} \\
\hline & $3 \mathrm{~g} / 24 \mathrm{~h} / \mathrm{kg}$ body wt & $\begin{array}{l}\text { Ascites, } \\
\text { edema }\end{array}$ & [9] \\
\hline & $30 \mathrm{mg} / \mathrm{ml}$ & $\begin{array}{l}\text { Ascites, } \\
\text { edema }\end{array}$ & {$[9]$} \\
\hline $\begin{array}{l}\text { Wild type B6/D2 } \\
\text { mouse }\end{array}$ & $0.03 \mathrm{mg} / \mathrm{mg}$ creat & & [29] \\
\hline $\mathrm{ApoE}^{-/-}$mouse & $0.2 \mathrm{mg} / \mathrm{ml}$ & & [30] \\
\hline Cox2 tg mouse & $0.07 \mathrm{mg} / \mathrm{mg}$ creat & & [29] \\
\hline PRO/Re mouse & $\begin{array}{l}0.7 \mathrm{~g} / 24 \mathrm{~h} / \mathrm{kg} \\
\text { body wt }\end{array}$ & & [31] \\
\hline \multicolumn{4}{|l|}{ Injection of adriamycin } \\
\hline Sprague Dawley rat & $25 \mathrm{mg} / \mathrm{mg}$ creat & Na retention & {$[9]$} \\
\hline B6/D2 mouse & $0.04 \mathrm{mg} / \mathrm{mg}$ creat & & [41] \\
\hline Balb/c mouse & $23 \mathrm{mg} / \mathrm{mg}$ creat & & {$[42]$} \\
\hline Balb/c mouse & $226 \mathrm{mg} / \mathrm{mg}$ creat & & [43] \\
\hline 129 mouse & 120 mg/mg creat & Ascites & [44] \\
\hline \multicolumn{4}{|l|}{ Genetically modified mice } \\
\hline Laminin $\alpha 5^{-/-}$ & 200 mg/mg creat & & [32] \\
\hline Laminin $\beta 2^{--}$ & $12 \mathrm{mg} / \mathrm{ml}$ & & [33] \\
\hline$\alpha$-actinin- $4^{-/-}$ & ++ & & [34] \\
\hline $\mathrm{Nphs}^{-/-}$ & +++ & HTA & [36] \\
\hline $\mathrm{CD} 2-\mathrm{AP}^{-/-}$ & +++ & & [35] \\
\hline CD151 $1-$ & +++ & Edema & [27] \\
\hline
\end{tabular}

Human CD34

engraftment

NOD/SCID mouse $\quad 0.04 \mathrm{mg} / \mathrm{mg}$ creat

[37]

Proteinuria in PAN nephrotic rats is given as a function of the different units found in the literature. ++ and +++ refers to increases in proteinuria as determined by western blotting. When available, functional data related to renal sodium handling are provided; HTA, hypertension.

$\alpha$-actinin-4). Genetic inactivation of laminin $\alpha 5$ induced a marked proteinuria in some but not all mice [32]. Laminin $\beta 2$-deficient mice also displayed marked proteinuria, but the mice did not grow normally and died prematurely [33]. A similar phenotype was developed by $\alpha$-actinin-4- or CD2-associated protein-deficient mice $[34,35]$. These results clearly demonstrate the role of the targeted genes in the filtration barrier, but prove that the transgenic mouse lines generated are poor models for studying the mechanism of sodium retention, mainly because there is no evidence that these mice develop edema and/or ascites. This is possibly due to the premature death of all these gene-targeted mice. To circumvent the growth deficit associated with proteinuria during the development period, a model of inducible inactivation of podocin based on Cre-loxP technology was recently reported [36]. Interestingly, upon inactivation of podocin, these mice showed proteinuria, 
although it was not quantified, and hypertension, but no ascites or edema was described. In this model also, mice died prematurely as the median survival was 11 weeks following podocin loss. Mice with inactivation of CD151, a tetraspanin involved in the adhesion of podocytes to the basement membrane as well as in basement membrane integrity, deserve a special attention. As a matter of fact, CD151-deficient mice displayed marked, although not quantified, albuminuria and survived for at least 5 months. In addition, at this stage they were reported to exhibit edema [27]. Unfortunately renal function data (as opposed to morphological data) concerning these mice are scarce.

The last strategy consisted in developing a humanized model of nephrotic syndrome through engraftment of CD34 ${ }^{+}$cells from nephrotic patients in NOD/SCID mice [37]. These mice developed mild proteinuria (3fold increase) and the model is too tedious to be used routinely.

Adriamycin is also known to induce nephrotic syndrome in rat [38], and is often used to do the same in mouse. In rats, adriamycin induces a clear-cut proteinuria within 1-2 weeks after injection, although to a lesser extent than PAN. However, in terms of sodium retention the effect of adriamycin is transient and shows inter-individual differences in time-course [9], making it a poor model to study this phenomenon. In mouse, adriamycin-induced proteinuria is strain-dependent, with most strains being quite resistant to adriamycin and few ones developing nephrotic-range proteinuria within 1 week $[39,40]$. In an elegant study, Zheng et al. used inter-strain differences to identify by genome-wide analysis of linkage a locus on chromosome 16 associated with susceptibility to adriamycin, but they failed to identify the responsible gene [40]. They also found a modifier locus on chromosome 9. However, to our knowledge, sodium retention has not been documented in adriamycin-treated mice. Regarding tubular functions, a limit of the adriamycin model is that sensitive mouse strains develop not only focal segmental glomerulosclerosis but also tubulo-interstitial fibrosis and tubular lesions that rapidly progress towards renal insufficiency [40]. Thus, this is clearly not a relevant model to study increased sodium reabsorption.

\section{Conclusions}

Enhancing adenosine deaminase activity in podocytes is not sufficient to render mice sensitive to PAN in terms of nephrotic syndrome. The Ada ${ }^{\text {tg }}$ mouse line that we have generated might be useful as background for future attempts to transfer PAN-sensitivity in mice, since adenosine deaminase activity remains necessary, but not sufficient, to provide sensitivity to PAN.

\section{Acknowledgements}

The results presented in this paper have not been published elsewhere in whole or part. This work was supported by Agence Nationale de la Recherche (06-PHYSIO-035). We thank TAAM UPS44-SEAT (Service des Animaux Trangéniques), Villejuif, France (http://transgenose.cnrs-orleans.fr/ taam) for transgenesis experiments.

\section{Authors' contributions}

GB designed the study, carried out the experiments, undertook data analysis and wrote the manuscript. AD designed the study and wrote the manuscript

\section{Competing interests}

The authors declare that they have no competing interests.

Received: 9 April 2010 Accepted: 22 July 2010 Published: 22 July 2010

\section{References}

1. Doucet A, Favre G, Deschenes G: Molecular mechanism of edema formation in nephrotic syndrome: therapeutic implications. Pediatr Nephrol 2007, 22(12):1983-1990.

2. Frenk S, Antonowicz I, Craig JM, Metcoff J: Experimental nephrotic syndrome induced in rats by aminonucleoside; renal lesions and body electrolyte composition. Proc Soc Exp Biol Med 1955, 89(3):424-427.

3. Pedraza-Chaverri J, Cruz C, Ibarra-Rubio ME, Chavez MT, Calleja C, Tapia E, del Carmen Uribe M, Romero L, Pena JC: Pathophysiology of experimental nephrotic syndrome induced by puromycin aminonucleoside in rats. I. The role of proteinuria, hypoproteinemia, and renin-angiotensinaldosterone system on sodium retention. Rev Invest Clin 1990, 42(1):29-38.

4. Deschenes G, Wittner M, Stefano A, Jounier S, Doucet A: Collecting duct is a site of sodium retention in PAN nephrosis: a rationale for amiloride therapy. J Am Soc Nephrol 2001, 12(3):598-601.

5. Ichikawa I, Rennke HG, Hoyer JR, Badr KF, Schor N, Troy JL, Lechene CP, Brenner BM: Role for intrarenal mechanisms in the impaired salt excretion of experimental nephrotic syndrome. J Clin Invest 1983, 71(1):91-103.

6. Lourdel S, Loffing J, Favre G, Paulais M, Nissant A, Fakitsas P, Creminon C, Feraille E, Verrey F, Teulon J, et al: Hyperaldosteronemia and activation of the epithelial sodium channel are not required for sodium retention in puromycin-induced nephrosis. J Am Soc Nephrol 2005, 16(12):3642-3650.

7. Perico N, Delaini F, Lupini C, Benigni A, Galbusera M, Boccardo P, Remuzzi G: Blunted excretory response to atrial natriuretic peptide in experimental nephrosis. Kidney Int 1989, 36(1):57-64.

8. Rabelink AJ, Koomans HA, Gaillard CA, Dorhout Mees EJ: Renal response to atrial natriuretic peptide in nephrotic syndrome. Nephrol Dial Transplant 1987, 2(6):510-514.

9. Deschenes $\mathrm{G}$, Doucet A: Collecting duct $(\mathrm{Na}+/ \mathrm{K}+)$-ATPase activity is correlated with urinary sodium excretion in rat nephrotic syndromes. J Am Soc Nephrol 2000, 11(4):604-615.

10. Barlet-Bas C, Khadouri C, Marsy S, Doucet A: Sodium-independent in vitro induction of $\mathrm{Na}+, \mathrm{K}+-\mathrm{ATPase}$ by aldosterone in renal target cells: permissive effect of triiodothyronine. Proc Natl Acad Sci USA 1988, 85(5):1707-1711

11. Masilamani S, Kim GH, Mitchell C, Wade JB, Knepper MA: Aldosteronemediated regulation of $\mathrm{ENaC}$ alpha, beta, and gamma subunit proteins in rat kidney. J Clin Invest 1999, 104(7):R19-23.

12. de Seigneux S, Kim SW, Hemmingsen SC, Frokiaer J, Nielsen S: Increased expression but not targeting of $\mathrm{ENaC}$ in adrenalectomized rats with PAN-induced nephrotic syndrome. Am J Physiol Renal Physiol 2006, 291(1): F208-217.

13. Nosaka K, Takahashi T, Nishi T, Imaki H, Suzuki T, Suzuki K, Kurokawa K, Endou $\mathrm{H}$ : An adenosine deaminase inhibitor prevents puromycin aminonucleoside nephrotoxicity. Free Radic Biol Med 1997, 22(4):597-605.

14. Xia L, Zhou M, Kalhorn TF, Ho HT, Wang J: Podocyte-specific expression of organic cation transporter PMAT: implication in puromycin aminonucleoside nephrotoxicity. Am J Physiol Renal Physiol 2009, 296(6): F1307-1313.

15. Morla L, Crambert G, Mordasini D, Favre G, Doucet A, Imbert-Teboul M: Proteinase-activated receptor 2 stimulates $\mathrm{Na}, \mathrm{K}$-ATPase and sodium reabsorption in native kidney epithelium. J Biol Chem 2008, 283(42):28020-28028 
16. Chinsky JM, Ramamurthy V, Fanslow WC, Ingolia DE, Blackburn MR, Shaffer KT, Higley HR, Trentin JJ, Rudolph FB, Knudsen TB, et al: Developmental expression of adenosine deaminase in the upper alimentary tract of mice. Differentiation 1990, 42(3):172-183.

17. Barton R, Martiniuk F, Hirschhorn R, Goldschneider I: The distribution of adenosine deaminase among lymphocyte populations in the rat. $J$ Immunol 1979, 122(1):216-220.

18. Disset A, Cheval L, Soutourina O, Duong Van Huyen JP, Li G, Genin C, Tostain J, Loupy A, Doucet A, Rajerison R: Tissue compartment analysis for biomarker discovery by gene expression profiling. PLoS One 2009, 4(11): e7779.

19. Chabardes-Garonne D, Mejean A, Aude JC, Cheval L, Di Stefano A, Gaillard MC, Imbert-Teboul M, Wittner M, Balian C, Anthouard V, et al: A panoramic view of gene expression in the human kidney. Proc Natl Acad Sci USA 2003, 100(23):13710-13715.

20. Macary G, Rossert J, Bruneval P, Mandet C, Belair MF, Houillier P, Van Huyen JP: Transgenic mice expressing nitroreductase gene under the control of the podocin promoter: a new murine model of inductible glomerular injury. Virchows Arch 456(3):325-337.

21. Beaman M, Birtwistle R, Howie AJ, Michael J, Adu D: The role of superoxide anion and hydrogen peroxide in glomerular injury induced by puromycin aminonucleoside in rats. Clin Sci (Lond) 1987, 73(3):329-332.

22. Gwinner W, Landmesser U, Brandes RP, Kubat B, Plasger J, Eberhard O, Koch KM, Olbricht $\mathrm{CJ}$ : Reactive oxygen species and antioxidant defense in puromycin aminonucleoside glomerulopathy. J Am Soc Nephrol 1997, 8(11):1722-1731.

23. Rincon J, Romero M, Viera N, Pedreanez A, Mosquera J: Increased oxidative stress and apoptosis in acute puromycin aminonucleoside nephrosis. Int J Exp Pathol 2004, 85(1):25-33.

24. Diamond JR, Bonventre JV, Karnovsky MJ: A role for oxygen free radicals in aminonucleoside nephrosis. Kidney Int 1986, 29(2):478-483.

25. Thakur V, Walker PD, Shah SV: Evidence suggesting a role for hydroxyl radical in puromycin aminonucleoside-induced proteinuria. Kidney Int 1988, 34(4):494-499.

26. Nagasawa HT, Swingle KF, Alexander CS: Metabolism of aminonucleoside8-14C in the rat and guinea pig. Biochem Pharmacol 1967, 16(11):2211-2219.

27. Baleato RM, Guthrie PL, Gubler MC, Ashman LK, Roselli S: Deletion of CD151 results in a strain-dependent glomerular disease due to severe alterations of the glomerular basement membrane. Am J Pathol 2008, 173(4):927-937.

28. Maier SM, Gross JK, Hamlin KL, Maier JL, Workman JL, Kim-Howard XR, Schoeb TR, Farris AD: Proteinuria of nonautoimmune origin in wild-type FVB/NJ mice. Comp Med 2007, 57(3):255-266.

29. Jo Yl, Cheng H, Wang S, Moeckel GW, Harris RC: Puromycin induces reversible proteinuric injury in transgenic mice expressing cyclooxygenase-2 in podocytes. Nephron Exp Nephrol 2007, 107(3):e87-94.

30. Cheng ZZ, Patari A, Aalto-Setala K, Novikov D, Schlondorff D, Holthofer H: Hypercholesterolemia is a prerequisite for puromycin inducible damage in mouse kidney. Kidney Int 2003, 63(1):107-112.

31. Kanwar YS, Manaligod JR, Krakower CA: Aminonucleoside nephrosis in PRO/Re mice. Proc Soc Exp Biol Med 1977, 155(3):339-345.

32. Goldberg S, Adair-Kirk TL, Senior RM, Miner JH: Maintenance of Glomerular Filtration Barrier Integrity Requires Laminin \{alpha\}5. J Am Soc Nephrol.

33. Noakes PG, Miner JH, Gautam M, Cunningham JM, Sanes JR, Merlie JP: The renal glomerulus of mice lacking s-laminin/laminin beta 2: nephrosis despite molecular compensation by laminin beta 1. Nat Genet 1995, 10(4):400-406

34. Kos CH, Le TC, Sinha S, Henderson JM, Kim SH, Sugimoto H, Kalluri R, Gerszten RE, Pollak MR: Mice deficient in alpha-actinin-4 have severe glomerular disease. J Clin Invest 2003, 111(11):1683-1690.

35. Shih NY, Li J, Karpitskii V, Nguyen A, Dustin ML, Kanagawa O, Miner JH, Shaw AS: Congenital nephrotic syndrome in mice lacking CD2-associated protein. Science 1999, 286(5438):312-315.

36. Mollet G, Ratelade J, Boyer O, Muda AO, Morisset L, Lavin TA, Kitzis D, Dallman MJ, Bugeon L, Hubner N, et al: Podocin inactivation in mature kidneys causes focal segmental glomerulosclerosis and nephrotic syndrome. J Am Soc Nephrol 2009, 20(10):2181-2189.

37. Sellier-Leclerc AL, Duval A, Riveron S, Macher MA, Deschenes G, Loirat C, Verpont MC, Peuchmaur M, Ronco P, Monteiro RC, et al: $\mathrm{A}$ humanized mouse model of idiopathic nephrotic syndrome suggests a pathogenic role for immature cells. J Am Soc Nephrol 2007, 18(10):2732-2739.

38. Bertani T, Poggi A, Pozzoni R, Delaini F, Sacchi G, Thoua Y, Mecca G, Remuzzi G, Donati MB: Adriamycin-induced nephrotic syndrome in rats: sequence of pathologic events. Lab Invest 1982, 46(1):16-23.

39. Lenderink AM, Liegel K, Ljubanovic D, Coleman KE, Gilkeson GS, Holers VM, Thurman JM: The alternative pathway of complement is activated in the glomeuli and tubulointerstitium of mice with adriamycin nephropathy. Am J Physiol Renal Physiol 2007, 293(2):F555-564.

40. Zheng Z, Schmidt-Ott KM, Chua S, Foster KA, Frankel RZ, Pavlidis P, Barasch J, D'Agati VD, Gharavi AG: A Mendelian locus on chromosome 16 determines susceptibility to doxorubicin nephropathy in the mouse. Proc Natl Acad Sci USA 2005, 102(7):2502-2507.

41. Cheng H, Fan X, Guan Y, Moeckel GW, Zent R, Harris RC: Distinct roles for basal and induced COX-2 in podocyte injury. J Am Soc Nephrol 2009, 20(9):1953-1962.

42. Vielhauer V, Berning E, Eis V, Kretzler M, Segerer S, Strutz F, Horuk R, Grone HJ, Schlondorff D, Anders HJ: CCR1 blockade reduces interstitial inflammation and fibrosis in mice with glomerulosclerosis and nephrotic syndrome. Kidney Int 2004, 66(6):2264-2278.

43. Hahn H, Park YS, Ha IS, Cheong HI, Choi Y: Age-related differences in adriamycin-induced nephropathy. Pediatr Nephrol 2004, 19(7):761-766.

44. Artunc F, Nasir O, Amann K, Boini KM, Haring HU, Risler T, Lang F: Serumand glucocorticoid-inducible kinase 1 in doxorubicin-induced nephrotic syndrome. Am J Physiol Renal Physiol 2008, 295(6):F1624-1634.

\section{Pre-publication history}

The pre-publication history for this paper can be accessed here: http://www.biomedcentral.com/1471-2369/11/15/prepub

doi:10.1186/1471-2369-11-15

Cite this article as: Brideau and Doucet: Over-expression of adenosine deaminase in mouse podocytes does not reverse puromycin aminonucleoside resistance. BMC Nephrology 2010 11:15.

\section{Submit your next manuscript to BioMed Central and take full advantage of:}

- Convenient online submission

- Thorough peer review

- No space constraints or color figure charges

- Immediate publication on acceptance

- Inclusion in PubMed, CAS, Scopus and Google Scholar

- Research which is freely available for redistribution

Submit your manuscript at www.biomedcentral.com/submit
C) Biomed Central 